\title{
PENGARUH PERUBAHAN LUAS HUTAN MANGROVE TERHADAP KONSENTRASI TOTAL SUSPENDED MATTER (TSM) DI MUARA PERANCAK, JEMBRANA - BALI
}

\section{THE EFFECT OF MANGROVE FOREST AMENDMENT TO TOTAL SUSPENDED MATTER (TSM) CONCENTRATION IN PERANCAK ESTAURINE, JEMBRANA - BALI}

\author{
Komang Iwan Suniada \& Liuta Yamano Aden \\ Balai Riset dan Observasi Laut \\ J1. Baru Perancak, Jembrana, Bali 82251, Indonesia \\ e-mail : komang.prtk@gmail.com
}

Diterima tanggal: 24 Agustus 2018 ; diterima setelah perbaikan: 15 April 2019 Disetujui tanggal: 20 April 2019 DOI: http://dx.doi.org/10.15578/jkn.v14i1.6864

\begin{abstract}
ABSTRAK
Data penginderaan jauh satelit Landsat dengan akurasi yang tinggi menjadikannya sangat layak digunakan sebagai salah satu alternatif untuk memetakan sebaran mangrove. Selain akurasi tinggi, monitoring luasan hutan mangrove dengan menggunakan data satelit penginderaan jauh dapat dilakukan secara berkala dengan lebih cepat dan biaya yang tidak terlalu mahal. Kajian mengenai fungsi hutan mangrove sebagai perangkap sedimen telah banyak dilakukan dengan menggunakan metode pengukuran lapangan, namun masih sedikit penelitian yang menghubungkan Total Suspended Matter (TSM) dengan perubahan luasan hutan mangrove yang sepenuhnya memanfaatkan data satelit penginderaan jauh menyebabkan penelitian ini sangat menarik dan cukup penting untuk dilakukan. Penelitian ini dilakukan di kawasan estuari Perancak yang merupakan salah satu kawasan ekosistem mangrove yang ada di Bali selain Taman Nasional Bali Barat, Taman Hutan Rakyat Benoa dan Nusa Lembongan. Data yang digunakan untuk menghasilkan informasi TSM dan perubahan luasan hutan mangrove pada penelitian ini adalah data citra satelit resolusi menengah, Landsat. Data pendukung yang digunakan adalah data pasang surut dan data curah hujan. Informasi sebaran hutan mangrove dilakukan dengan menggunakan data pada 2005 dan 2015 dengan metode supervised maximum likelihood, sedangkan informasi konsentrasi TSM diperoleh dengan menggunakan data pada 2002 dan 2016 dengan menggunakan algoritma Budhiman LAPAN. Hasil kajian menunjukkan bahwa seiring dengan penambahan luas hutan mangrove di kawasan estuari Perancak telah menyebabkan penurunan konsentrasi TSM di muara sungai Perancak. Penurunan itu disebabkan karena terdapat sedimen yang terperangkap dan mengendap disekitar pohon ataupun akar mangrove terutama mangrove jenis Rhizophora. Selain penambahan luas hutan mangrove, faktor oseanografi pasang surut juga sangat berpengaruh terhadap fluktuasi TSM di sekitar muara Perancak.
\end{abstract}

Kata kunci: Mangrove, total suspended metter, Muara Perancak, landsat, pasang surut.

\section{ABSTRACT}

Remote sensing data from Landsat satellite with its high accuracy is very feasible to use as an alternative to mapping mangrove distribution. Besides its accuracy, mangrove monitoring using remote sensing data can be done frequently and with low cost. Study of the function of mangrove forests as a sediment trap has been largely undertaken using field measurement methods, but only a few researches that fully utilize remote sensing data to find out the influence of mangrove forest's area changes against the Total Suspended Matter (TSM) making this study very interesting and important to do. This research was conducted in Perancak estuary area which is one of mangrove ecosystem area in Bali besides West Bali National Park, Benoa Forest Park and Nusa Lembongan. The data used to generate TSM information and change of mangrove forest area in this research is medium resolution satellite image data, Landsat. Tidal data and rainfall data were used as a supporting data. Mangrove distribution was analysed using supervised maximum likelihood method over Landsat data year 2005 and 2015 while the information of TSM concentration was obtained using Budhiman'S algorithm LAPAN over Landsat data year 2002 and 2016. Result shows that the increasing of mangrove forest area has caused the decreasing of TSM concentration at mouth Perancak river. The reduction was caused by sediments trapped and settled around trees or mangrove roots, especially type of Rhizophora. Besides the increasing of mangrove forest area, the

Pengaruh Perubahan Luas Hutan Mangrove Terhadap Konsentrasi Total Suspended Matter (TSM) di Muara Perancak, Jembrana - Bali - Komang Iwan Suniada \& Liuta Yamano Aden 


\section{Keywords: Mangrove, total suspended metter, Perancak Estaurine, remote sensing, landsat.}

\section{PENDAHULUAN}

Ekosistem mangrove merupakan ekosistem peralihan antara darat dan laut serta dikenal mempunyai berbagai peran yang sangat penting, baik peran secara ekologis maupun peran secara ekonomis. Secara ekologis, hutan mangrove merupakan tempat pembesaran ikan (nursery ground) yang berpengaruh terhadap produktifitas perikanan serta siklus nutrien (Donato et al., 2011), pelindung pantai dari abrasi dan tsunami (Spalding et al., 2014) serta pengikat sedimen yang terlarut pada perairan. Secara ekonomis hutan mangrove memberikan manfaat sebagai sumber untuk kayu bakar dan arang, sebagai bahan baku kerajinan tradisional serta bahan baku untuk olahan makanan serta minuman. Selain manfaat tersebut, salah satu fungsi penting hutan mangrove yang berdampak global adalah sangat efektif sebagai penyerap karbon (Komiyama et al., 2008). Mengingat pentingnya peranan hutan mangrove tersebut, perlu dilakukan monitoring secara berkala pada suatu kawasan mangrove untuk mengetahui kondisi terkininya, karena menurut Donato et al. (2011) telah terjadi pengurangan luasan sekitar 30-50\% dalam setengah abad terakhir sebagai akibat dari pembangunan besar-besaran di daerah pesisir, perluasan daerah lokasi budidaya serta penebangan hutan mangrove secara berlebihan.

Schmitt \& Duke (2015) menyatakan salah satu data yang sangat berguna untuk monitoring mangrove adalah dengan menggunakan data satelit penginderaan jauh karena mampu memberikan informasi secara spasial dan temporal mengenai area, sebaran spesies, kondisi dan juga perubahan populasi. Sulong et al. (2002) menyatakan bahwa tingkat akurasi untuk memetakan sebaran mangrove dengan menggunakan data citra satelit Landsat adalah 87,8\%. Tingginya akurasi ini membuat penggunaan data citra satelit Landsat sangat layak untuk digunakan sebagai salah satu teknik untuk memetakan sebaran mangrove. Selain akurasi tinggi, monitoring luasan hutan mangrove dengan menggunakan data satelit penginderaan jauh dapat dilakukan secara berkala dengan lebih cepat dan biaya yang tidak terlalu mahal. Beberapa kajian mangrove yang memanfaatkan data satelit penginderaan jauh diantaranya adalah untuk mengetahui perubahan luasan hutan mangrove dengan menggunakan dua data pada lokasi yang sama dengan rentang waktu yang berbeda (Haryani, 2013); kajian untuk memetakan sebaran dan kerapatan mangrove di Segara Anakan, Cilacap (Purwanto et al., 2014); serta kajian pendahuluan untuk menghitung stok karbon (above ground dan below ground carbon stock) di kawasan estuary Perancak dengan menggunakan data citra satelit Landsat (Hastuti et al., 2017).

Penelitian mengenai peranan hutan mangrove sebagai perangkap sedimen telah dilakukan dengan metode pengukuran lapangan (Roza, 2016; Petra et al., 2012), namun minimnya informasi mengenai pengaruh hutan mangrove terhadap konsentrasi sedimen atau padatan tersuspensi pada perairan dengan menggunakan metode penginderaan jauh menyebabkan kajian ini cukup penting dan menarik untuk dilakukan. Material tersuspensi pada perairan dengan ukuran $>1 \mu \mathrm{m}$ atau dikenal dengan istilah Total Suspended Matter (TSM) umumnya terdiri dari lumpur, pasir halus dan mikro organisme serta dapat diamati dengan menggunakan metode penginderaan jauh (Budhiman, 2005). Semakin tinggi nilai TSM pada suatu perairan akan berakibat pada menurunnya kualitas perairan karena terhalangnya penetrasi sinar matahari ke dalam kolom perairan sehingga dapat mengganggu proses fotosintesis.

Tujuan dari penelitian ini adalah untuk mengetahui pengaruh perubahan luas hutan mangrove yang terdapat di estuari Perancak terhadap konsentrasi TSM di muara Perancak, Jembrana - Bali dengan menggunakan data penginderaan jauh.

\section{BAHAN DAN METODE}

\section{Lokasi Penelitian}

Penelitian ini dilakukan di kawasan estuari Perancak, Kabupaten Jembrana - Bali. Kawasan estuari Perancak yang terletak pada koordinat $8^{\circ} 22^{\prime} 30^{\prime \prime} \mathrm{LS}-8^{\circ} 24^{\prime} 18^{\prime \prime} \mathrm{LS}$ dan $114^{\circ} 36^{\prime} 18^{\prime \prime}$ BT- $114^{\circ} 38^{\prime} 31.2^{\prime \prime}$ 'BT memiliki luas 2.512,69 ha terdiri dari kawasan hutan mangrove alami maupun hutan mangrove hasil penanaman kembali pada lahan bekas tambak budidaya udang dan bandeng yang saat ini tidak berfungsi.

\section{Pengumpulan Data}

Data yang digunakan pada penelitian ini adalah data citra satelit Landsat untuk pemetaan perubahan mangrove dan TSM serta data pasang surut dan data 


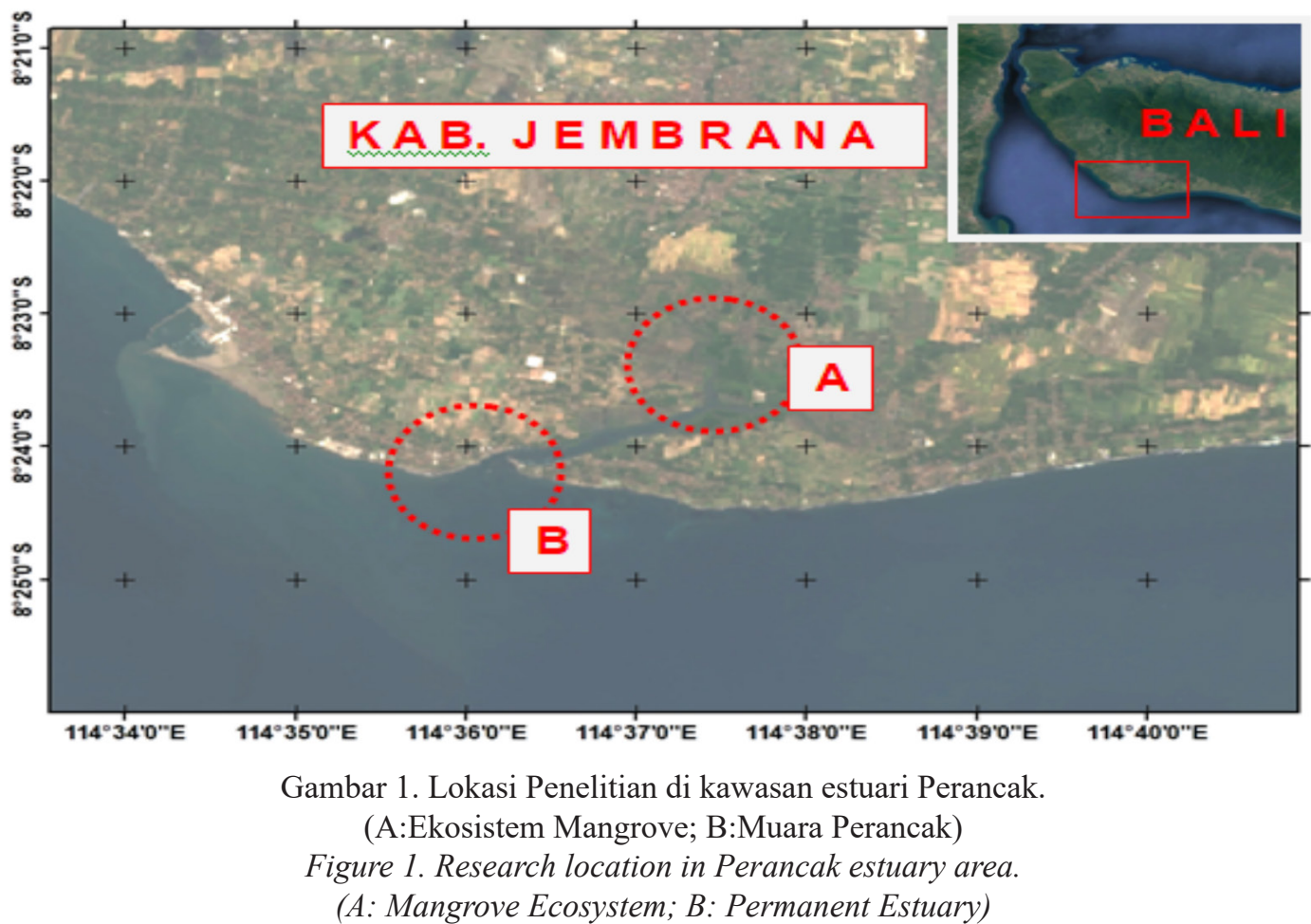

curah hujan yang merupakan data pendukung untuk mengetahui kondisi lingkungan sekitar daerah kajian pada saat perekaman data citra satelit Landsat.

Data satelit Landsat (path/row : 117/066) yang digunakan untuk memetakan TSM di muara Perancak terdiri dari 4 data, yaitu :

1. data hasil akuisisi tanggal 28 Mei 2002, jam 02:18:36 (27 Mei 2002 jam 14:18:36 WITA) yang merepresentasikan konsentrasi TSM pada musim kemarau ketika mangrove masih sedikit;

2. data tanggal 26 Mei 2016, jam 02:29:36 (25 Mei 2016 jam 14:29:36 WITA) yang merepresentasikan konsentrasi TSM pada musim kemarau ketika mangrove semakin banyak;

3. data tanggal 3 Oktober 2002, jam 02:17:41 (2 Oktober 2002, jam 14:17:41 WITA) yang merepresentasikan konsentrasi TSM pada musim hujan ketika mangrove masih sedikit;

4. data tanggal 1 Oktober 2016, jam 02:30:13 (30 September 2016, jam 14:30:13 WITA) yang diasumsikan merupakan representasi konsentrasi TSM pada musim hujan ketika mangrove semakin banyak. Data satelit Landsat diperoleh dari https://earthexplorer. usgs.gov, website milik Badan Survei Geologi Amerika Serikat (United States Geological Survey; USGS), suatu badan ilmiah milik pemerintah Amerika Serikat yang bertugas secara khusus untuk mempelajari lansekap, sumberdaya dan bencana alam.

Berbeda dengan analisis TSM yang menggunakan data pada 2002 dan 2016, informasi perubahan luas

hutan mangrove di estuari Perancak diperoleh dengan menggunakan data sekunder memanfaatkan hasil kajian dari Hastuti et al. (2018). Overall accuracy (akurasi keseluruhan) dihitung dengan menggunakan metode Accuracy Assessment Using Random Points and the Semi-Automatic Classification Plugin for QGIS. Informasi tambahan mengenai perubahan luasan mangrove di estuari Perancak diperoleh dengan memanfaatkan hasil penelitian dari Rahmania et al. (2015) dan Proisy et al. (2017) yang menggunakan beberapa citra satelit resolusi tinggi seperti Quickbird, Ikonos, GeoEye, WorldView pada periode 2001 - 2015 sehingga sangat detail untuk mengamati perubahan ekosistem mangrove di estuari Perancak dari tahun ke tahun.

Data pasang surut pada 27 Mei 2002, 2 Oktober 2002, 25 Mei 2016 dan 30 September 2016 diperoleh dari website Balai Riset dan Observasi Laut (http://www. bpol.litbang.kkp.go.id/imro-ofs) merupakan data pendukung untuk mengetahui kondisi pasang surut perairan pada saat akusisi data Landsat.

Data curah hujan harian pada Mei dan Oktober 2002 dan 2016 diperoleh dari website Badan Meteorologi Klimatologi dan Geofisika, BMKG (http://dataonline. bmkg.go.id/data_iklim) setelah melakukan registrasi. Data yang tersedia merupakan data harian yang berasal dari stasiun pengamatan yang terdekat dengan lokasi penelitian, yaitu Stasiun Klimatologi Jembrana.

Pengaruh Perubahan Luas Hutan Mangrove Terhadap Konsentrasi Total Suspended Matter (TSM) di Muara Perancak, Jembrana - Bali - Komang Iwan Suniada \& Liuta Yamano Aden 


\section{Analisis Data}

Sebaran konsentrasi TSM di Muara Perancak dapat dipantau dari citra satelit Landsat dengan menggunakan persamaan Budhiman (2004) :

$\operatorname{TSM}(\mathrm{mg} / \mathrm{l})=8,1429 * \exp ^{(23,704 \text { * band merah })}$

Persamaan tersebut digunakan pada keempat data citra satelit Landsat sehingga diperoleh informasi TSM yang mepresentasikan perubahan konsentrasi TSM pada 2002 ke 2016 pada waktu musim kemarau serta perubahan konsentrasi TSM pada 2002 ke 2016 pada waktu musim hujan. Nilai TSM yang merepresentasikan muara Perancak di ekstrak pada koordinat 114³6'9" BT dan 8'24'11" LS (Gambar 1) Persentase perubahan konsentrasi TSM yang terjadi di muara Perancak dalam kurun waktu pada 2002 hingga 2016 baik itu ketika musim kemarau ataupun musim hujan dapat diketahui dengan menggunakan persamaan matematika sederhana :

$$
\text { Perubahan (\%) }=\frac{\mathrm{TSM}_{2016}-\mathrm{TSM}_{2002}}{\mathrm{TSM}_{2002}} \times 100 \%
$$

Klasifikasi vegetasi mangrove dan non-mangrove dapat dibedakan dengan menggunakan komposit band pada citra satelit. Komposit band dalam penghitungan luas mangrove menggunakan Landsat 7 ETM+ adalah RGB 453, sedangkan untuk Landsat 8 OLI/TIRS adalah RGB 564 (Purwanto et al., 2014). Untuk mengidentifikasi vegetasi mangrove dan non-mangrove dilakukan klasifikasi terbimbing dengan metode maximum likelihood (supervised maximum likelihood). Klasifikasi maximum likelihood merupakan suatu metode yang digunakan dengan mempertimbangkan berbagai faktor diantaranya adalah nilai suatu pixel yang memiliki nilai yang sama akan dikelompokan kedalam nilai pixel yang sama pula atau dengan kata lain Marini et al. (2014) menyatakan bahwa klasifikasi supervised maximum likelihood merupakan klasifikasi yang berpedoman pada nilai piksel yang sudah dikategori obyeknya atau dibuat dalam training sampel untuk masing-masing obyek penutup lahan. Menurut Jhonnerie et al. (2014) menyatakan bahwa overall accuracy untuk pemetaan mangrove dengan Landsat adalah berkisar antara 82,6\%-88,4\% dengan nilai Kappa yang berkisar antara 0,76-0,84; sedangkan Alimudi et al. (2017) menyatakan bahwa kisaran untuk overall accuracy untuk pemetaan mangrove dengan menggunakan data satelit Landsat adalah berkisar antara 85\%-88\% dengan nilai Kappa 0,78-0,83. Setelah diperoleh informasi luasan mangrove untuk data tahun 2005 dan 2015, selanjutnya dilakukan analisis tumpang susun (overlay) diantara kedua data tersebut untuk mengetahui perubahan luasan hutan mangrove dalam kurun waktu 10 tahun. Hasil analisis tumpang susun tersebut dapat memberikan informasi daerah-daerah yang mengalami penambahan luasan ataupun daerahdaerah yang mengalami pengurangan luasan hutan mangrove.

\section{HASIL DAN PEMBAHASAN}

\section{Sebaran Konsentrasi TSM}

Informasi sebaran konsentrasi TSM disekitar muara

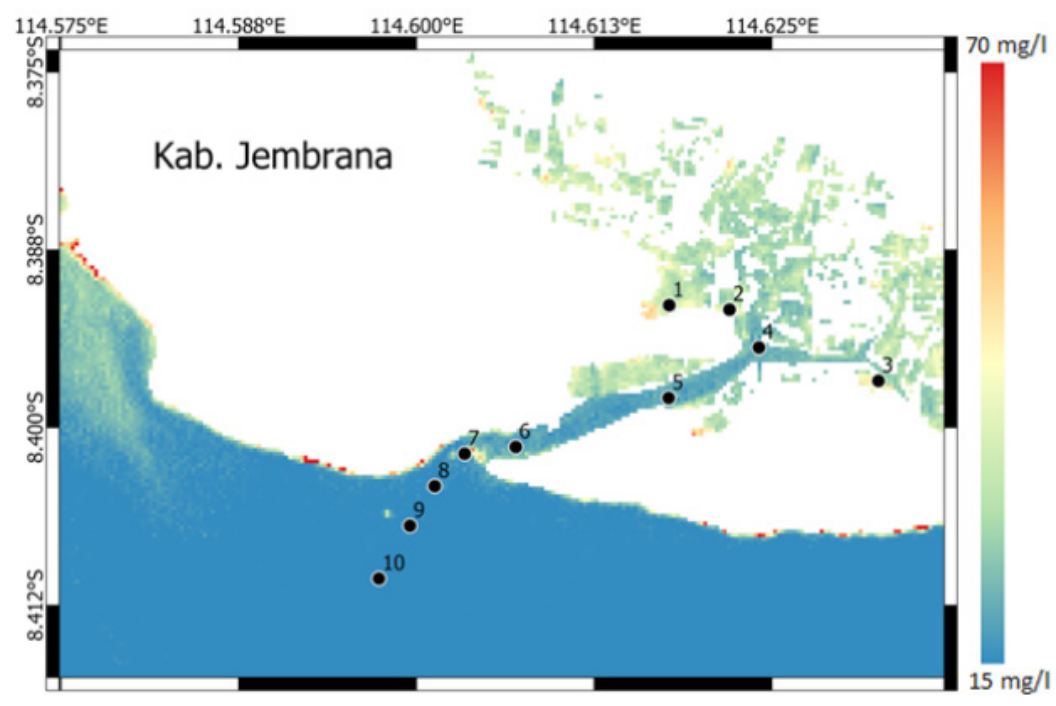

Gambar 2. Sebaran Spasial TSM 27 Mei 2002

Figure 2. Spatial Distribution of TSM in May 27, 2002.

JURNAL KELAUTAN NASIONAL, Vol. 14, No 1, April 2019, Hal. 11-24 


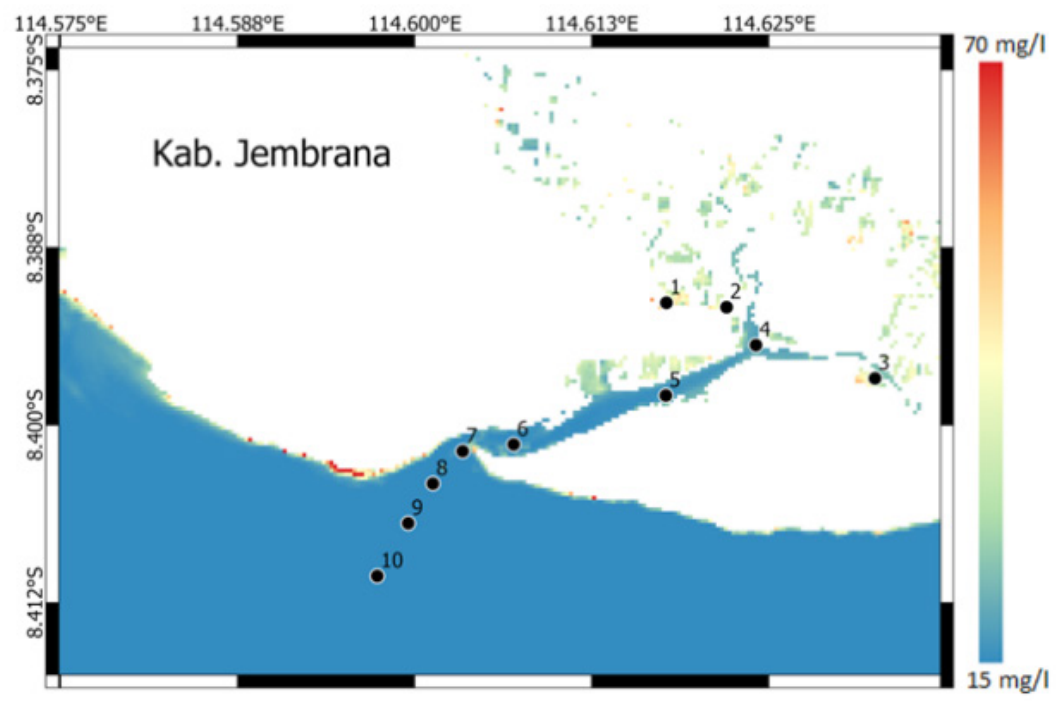

Gambar 3. Sebaran Spasial TSM 25 Mei 2016.

Figure 3. Spatial Distribution of TSM in May 25, 2016.

Perancak pada 27 Mei 2002 yang dihasilkan dengan menggunakan persamaan Budhiman (2004) dapat dilihat pada Gambar 2. Rata-rata TSM pada seluruh gambar tersebut adalah $18,95 \mathrm{mg} / \mathrm{l}$, dengan nilai minimum sebesar $14,06 \mathrm{mg} / \mathrm{l}$ dan nilai maksimum yang dapat mencapai $247,73 \mathrm{mg} / 1$.

Sedangkan informasi TSM pada 25 Mei 2016 menunjukkan bahwa rata-rata TSM adalah $17,34 \mathrm{mg} / 1$ dengan nilai minimum $15,62 \mathrm{mg} / \mathrm{l}$ dan nilai maksimum $127,95 \mathrm{mg} / \mathrm{l}$. Sebaran spasial konsentrasi TSM pada tanggal 25 Mei 2016 dapat dilihat pada Gambar 3.

Konsentrasi TSM yang diekstrak pada 10 titik yang dipilih secara acak dan dianggap mewakili kondisi ekosistem mangrove (titik 1-5), muara Perancak (titik 6-8) hingga ke laut lepas (titik 9-10) menunjukkan bahwa konsetrasi TSM cenderung lebih tinggi pada ekosistem mangrove dan semakin berkurang hingga ke laut lepas baik itu untuk tahun 2002 maupun tahun 2016 (tabel 1).

Berdasarkan nilai yang diekstrak dari titik sampling, jika konsentrasi TSM pada 2002 dibandingkan dengan konsentrasi TSM pada 2016 akan terlihat bahwa konsentrasi TSM di wilayah ekosistem mangrove pada 2016 menunjukkan nilai yang lebih tinggi jika daripada tahun 2002, namun semakin menuju ke laut lepas konsentrasi TSM pada 2002 terlihat sedikit lebih tinggi dibandingkan dengan konsentrasi TSM pada 2016 (Gambar 4).

Faktor fisika oseanografi yaitu pasang surut merupakan salah satu faktor yang dominan dalam proses pergerakan sedimen dari laut menuju sungai dan juga dari sungai menuju laut. Hal ini terjadi karena

Tabel 1. Nilai TSM pada titik sampling

Table 1. TSM value at the sampling point

\begin{tabular}{lllll}
\hline Titik & $\begin{array}{l}\text { Posisi } \\
\text { Latitude }\end{array}$ & Longitude & $\begin{array}{l}\text { TSM }(\mathbf{m g} / \mathbf{l}) \\
\mathbf{2 0 0 2}\end{array}$ & $\begin{array}{l}\text { TSM (mg/l) } \\
\mathbf{2 0 1 6}\end{array}$ \\
\hline 1 & $-8,391$ & 114,618 & 35,582 & 56,446 \\
2 & $-8,392$ & 114,622 & 34,112 & 42,361 \\
3 & $-8,397$ & 114,633 & 34,112 & 35,840 \\
4 & $-8,394$ & 114,624 & 24,341 & 22,323 \\
5 & $-8,398$ & 114,618 & 25,390 & 22,047 \\
6 & $-8,401$ & 114,607 & 23,336 & 20,965 \\
7 & $-8,402$ & 114,603 & 22,372 & 20,349 \\
8 & $-8,404$ & 114,601 & 19,712 & 17,749 \\
9 & $-8,407$ & 114,600 & 17,369 & 17,068 \\
10 & $-8,411$ & 114,597 & 18,117 & 16,638
\end{tabular}

Pengaruh Perubahan Luas Hutan Mangrove Terhadap Konsentrasi Total Suspended Matter (TSM) di Muara Perancak, Jembrana - Bali - Komang Iwan Suniada \& Liuta Yamano Aden 


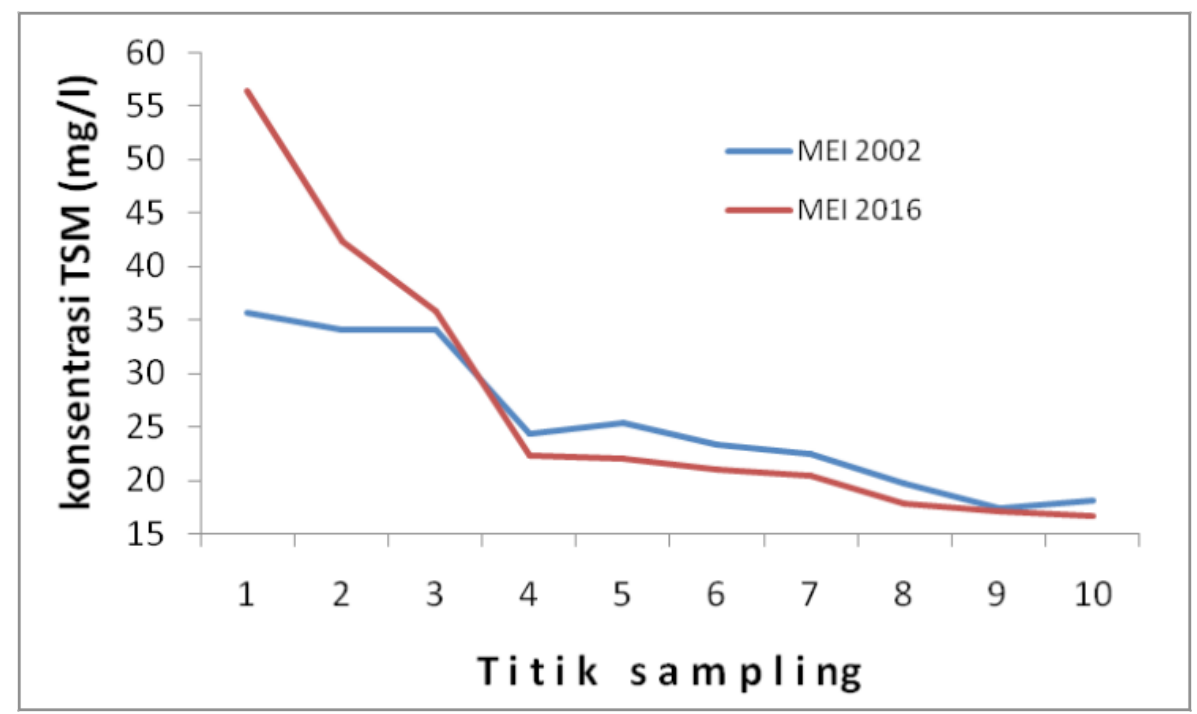

Gambar 4. Perbandingan antara TSM Mei 2002 dan Mei 2016 pada titik sampling. Figure 4. Comparison between TSM May 2002 and May 2016 at the sampling point.

pasang surut dapat membangkitkan arus yang dapat menyebabkan pergerakan massa air (Wibowo et al., 2016). Pergerakan massa air akibat pasang surut tersebut juga terjadi di wilayah perairan sekitar muara Perancak hingga ke kawasan mangrove. Ketika proses pasang berlangsung, sedimen di sekitar muara akan terbawa menuju ke sungai, sebaliknya ketika proses surut terjadi sedimen akan terbawa kembali dari sungai menuju ke muara. Tipe pasang surut yang terjadi di perairan Perancak adalah tipe campuran condong ke pasang surut ganda yang artinya bahwa dalam satu hari terjadi dua kali pasang namun tinggi dan interval waktu pasang naik tidak sama (Gambar 5). Kondisi pasang surut pada saat akusisi data satelit Landsat pada 27 Mei 2002 adalah sekitar tiga jam menuju surut terendah, dan empat jam menuju surut terendah pada 25 Mei 2016, hal ini berarti bahwa kondisi aliran massa air yang membawa sedimen sedang dalam proses bergerak menuju ke muara. Satriadi \& Widada (2004) menyatakan bahwa kondisi perairan relatif lebih tenang ketika surut, pengadukan dasar perairan di sekitar muara berkurang, kondisi dasar lebih stabil yang memungkinkan terjadi pengendapan sehingga menyebabkan penurunan konsentrasi TSM.

Selain pasang surut sebagai pembangkit arus, faktor curah hujan juga sangat berperan terhadap transpor sedimen dari sungai menuju ke laut, curah hujan yang terjadi di daerah hulu akan meningkatkan aliran air sungai menuju ke laut (Misra et al., 2014). Berdasarkan

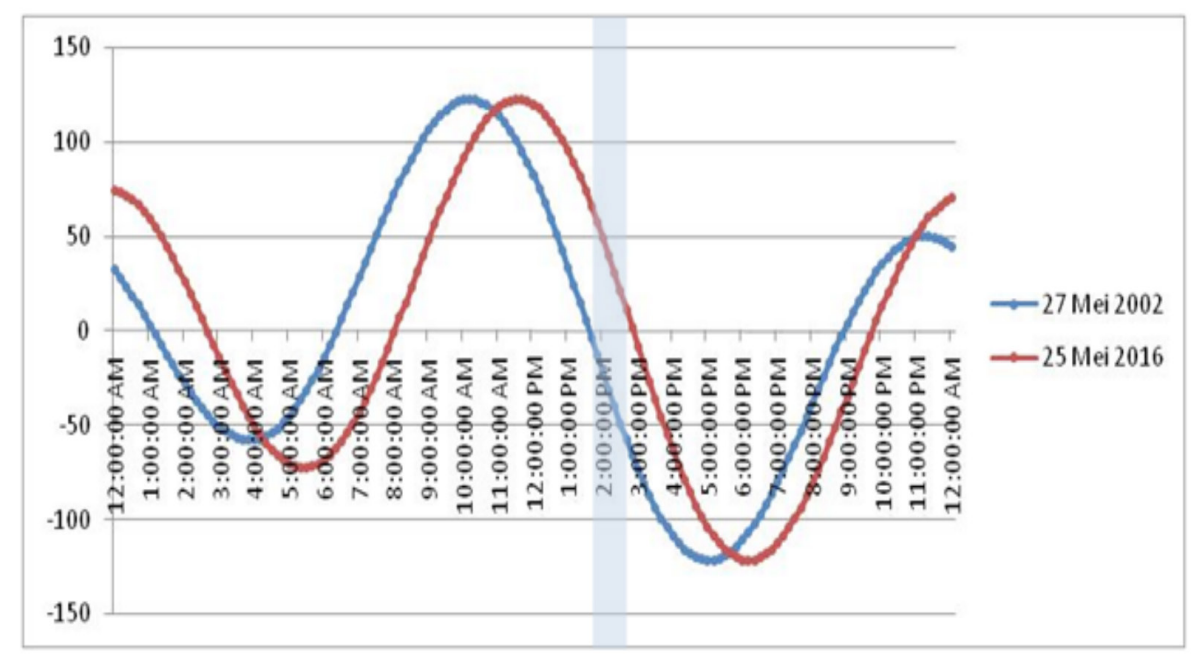

Gambar 5. Grafik pasang surut perairan Perancak Mei 2002 dan 2016.

Figure 5. Tidal charts of the May 2002 and 2016 in Perancak Coastal Waters. 


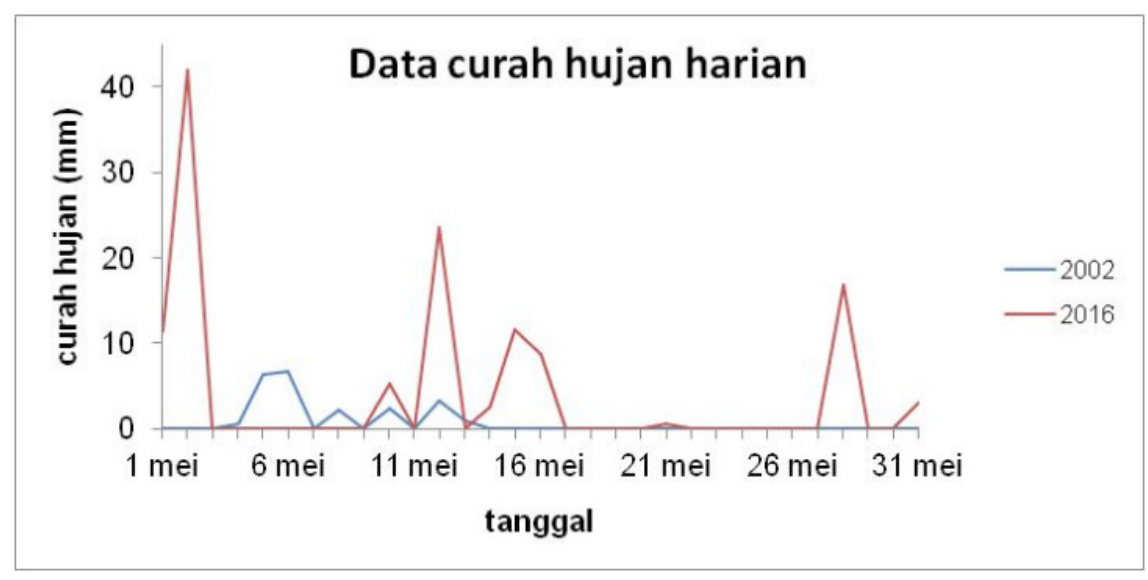

Gambar 6. Data curah hujan harian Bulan Mei tahun 2002 dan 2016.

Figure 6. Daily rainfall data for May 2002 and 2016.

data curah hujan harian yang diperoleh dari BMKG (Gambar 6), tidak terdapat perbedaan kondisi hujan pada saat akusisi data Landsat pada 27 Mei 2002 dan 25 Mei 2016.

Tidak adanya perbedaan konsentrasi TSM yang cukup signifikan diantara data pada Mei 2002 dan 2016 diduga terjadi karena pada saat akuisisi data, kondisi oseanografis pasang surut berada pada fase yang hampir sama, yaitu sama-sama berada pada fase menuju surut serta kondisi cuaca yang hampir sama yaitu pada saat akuisisi data citra satelit Landsat tersebut sedang tidak turun hujan.

Hasil pengolahan data pada 2 Oktober 2002 memberikan informasi bahwa nilai rata-rata TSM saat itu adalah sebesar 29,82 mg/l dengan nilai minimum sebesar $22,24 \mathrm{mg} / \mathrm{l}$ dan nilai maksimum yang dapat mencapai hingga $1.588,11 \mathrm{mg} / 1$. Sebaran spasial konsentrasi TSM pada 2 Oktober 2002 dapat dilihat pada Gambar 7.

Hasil perhitungan konsentrasi TSM pada 30 September 2016 menunjukkan bahwa nilai rata-rata TSM saat itu adalah sebesar $18,83 \mathrm{mg} / 1$ dengan nilai minimum sebesar $15,75 \mathrm{mg} / 1$ dan nilai maksimum yang dapat mencapai hingga 447,28 mg/l. Sebaran spasial konsentrasi TSM pada 30 September 2016 dapat dilihat pada Gambar 8.

Hasil ekstraksi nilai konsentrasi TSM pada 10 titik sampling yang mewakili kondisi ekosistem mangrove (titik 1-5), muara Perancak (titik 6-8) hingga ke laut lepas (titik 9-10) menunjukkan bahwa konsetrasi TSM cenderung lebih tinggi pada ekosistem mangrove dan semakin berkurang hingga ke laut lepas baik. Titik

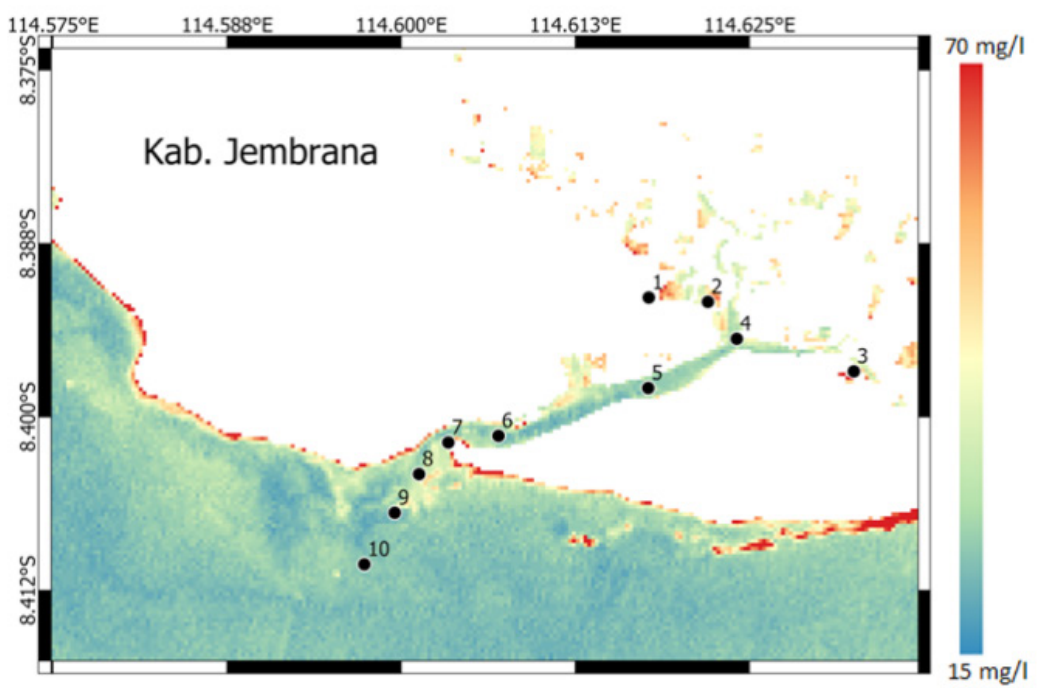

Gambar 7. Sebaran Spasial TSM 2 Oktober 2002.

Figure 7. Spatial Distribution of TSM in October 2, 2002.

Pengaruh Perubahan Luas Hutan Mangrove Terhadap Konsentrasi Total Suspended Matter (TSM) di Muara Perancak, Jembrana - Bali - Komang Iwan Suniada \& Liuta Yamano Aden 


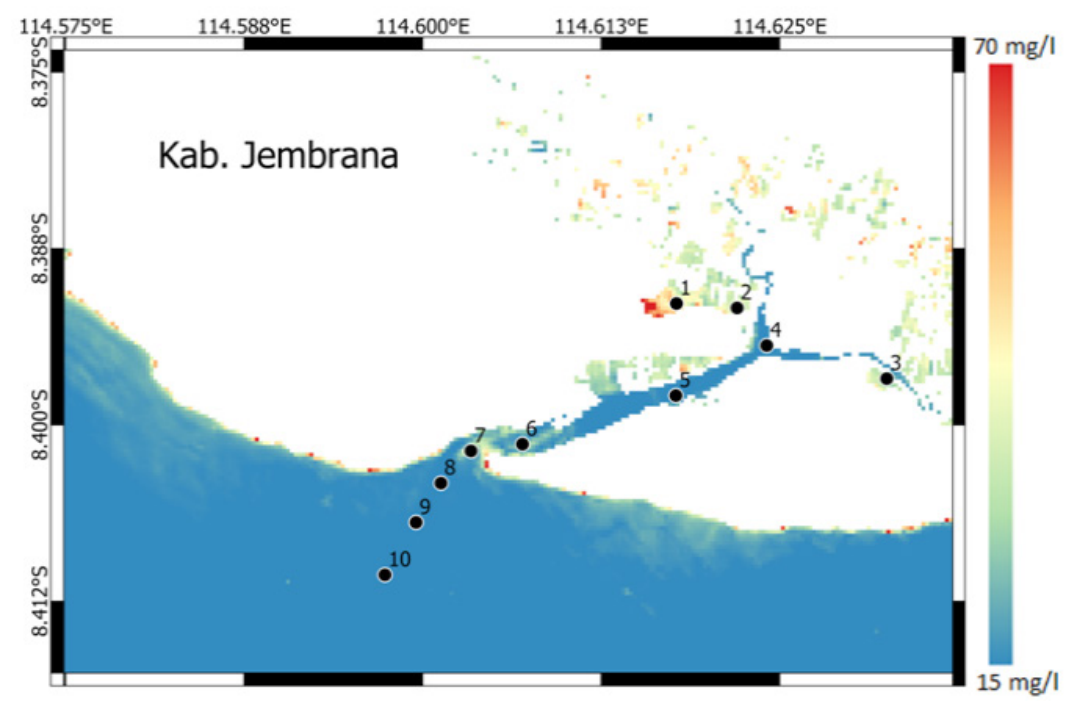

Gambar 8. Sebaran Spasial TSM 30 September 2016.

Figure 8. TSM Spatial Distribution in September 30, 2016.

7 yang merupakan titik sampling yang dekat dengan muara Perancak memperlihatkan kecenderungan nilai TSM yang cukup tinggi. Kecenderungan pola sebaran tersebut berlaku untuk tahun 2002 maupun tahun 2016 (tabel 2).

Perbandingan antara nilai konsentrasi TSM pada titik sampling pada Oktober 2002 dan September 2016 menunjukkan bahwa konsentrasi TSM 2Oktober 2002 cenderung lebih tinggi di sepanjang titik sampling (Gambar 9).

Perbedaan tersebut diduga terjadi karena akuisisi kedua data citra Landsat tersebut berada pada fase pasang surut yang berbeda (Gambar 10). Data Landsat pada 2 Oktober 2002 berada pada fase setelah kondisi perairan mencapai surut terendah menuju ke kondisi pasang, sedangkan data pada 30 September 2016 berada pada fase 2 jam menuju surut terendah.
Konsentrasi TSM yang lebih tinggi pada saat pasang sesuai dengan penelitian Satriadi \& Widada (2004) serta Wibowo et al. (2016) yang menyatakan bahwa arus dan gelombang yang terbentuk pada saat pasang lebih besar jika dibandingkan pada saat surut. Proses pengadukan sedimen terjadi secara lebih kuat pada saat pasang karena adanya pertemuan antara input massa air dari sungai dengan aliran massa air dari laut, sehingga menyebabkan meningkatnya konsentrasi TSM.

Secara umum pada Oktober 2016 curah hujan lebih sering terjadi dibandingkan periode 2002. Namun pada saat akuisisi data Landsat pada 2 Oktober 2002 dan 30 September 2016 kondisi cuaca sedang sama-sama tidak terjadi hujan, sehingga hasil analisis menunjukkan bahwa walaupun Oktober 2016 intensitas hujan lebih tinggi dari tahun 2002, konsentrasi TSM tahun 2016 lebih rendah daripada konsentrasi TSM tahun 2002. Hal ini menunjukkan bahwa ketika perairan berada

Tabel 2. Niilai TSM pada titik sampling

Table 2. TSM value at the sampling point

\begin{tabular}{lllll}
\hline Titik & \multicolumn{2}{c}{ Posisi } & $\begin{array}{l}\text { TSM (mg/l) } \\
\mathbf{2 0 0 2}\end{array}$ & $\begin{array}{l}\text { TSM (mg/l) } \\
\mathbf{2 0 1 6}\end{array}$ \\
\hline 2 & Latitude & Longitude & 49,409 & 38,407 \\
4 & $-8,392$ & 114,622 & 36,155 & 19,246 \\
5 & $-8,394$ & 114,624 & 30,396 & 19,573 \\
6 & $-8,398$ & 114,618 & 32,581 & 24,217 \\
7 & $-8,401$ & 114,607 & 41,539 & 25,128 \\
8 & $-8,402$ & 114,603 & 34,922 & 18,451 \\
9 & $-8,404$ & 114,601 & 25,554 & 19,225 \\
10 & $-8,407$ & 114,600 & 29,359 & 17,924 \\
\hline
\end{tabular}

JURNAL KELAUTAN NASIONAL, Vol. 14, No 1, April 2019, Hal. 11-24 


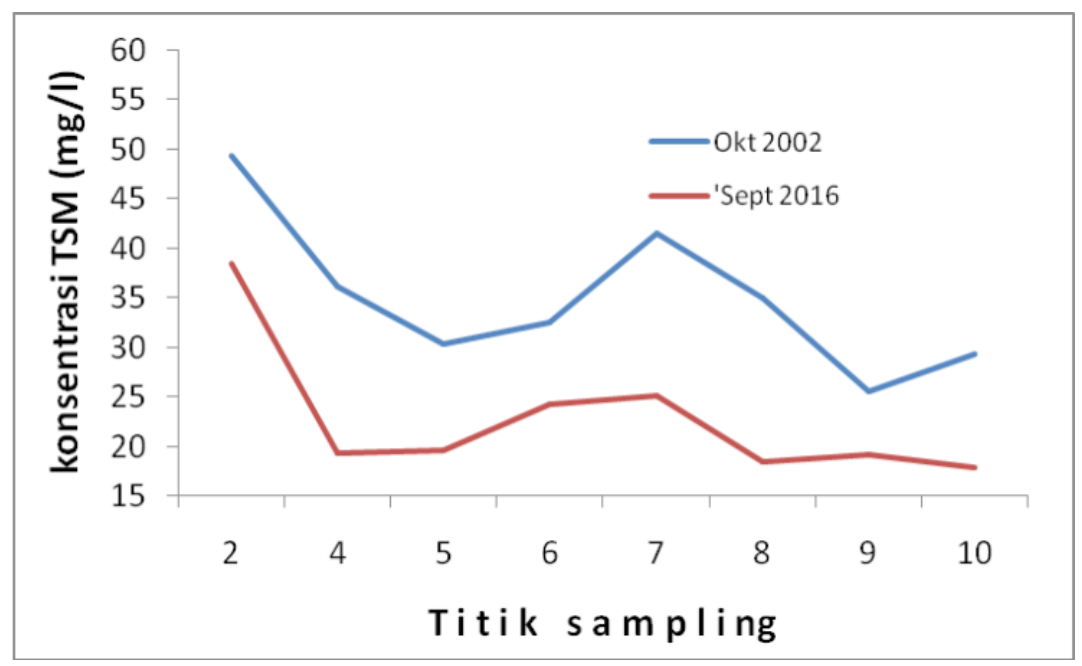

Gambar 9. Perbandingan antara TSM Oktober 2002 dan September 2016 pada titik sampling. Figure 9. Comparison between October 2002 TSM and September 2016 at the sampling point.

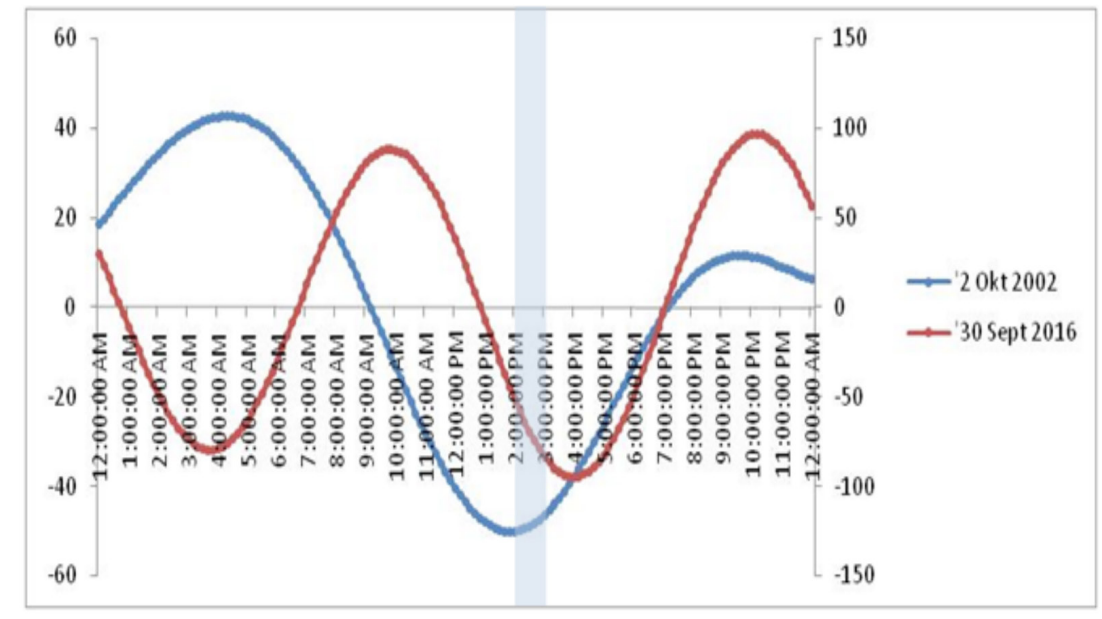

Gambar 10. Grafik pasang surut perairan Perancak pada Oktober 2002 dan September 2016.

Figure 10. Tidal charts of the Perancak Coastal Waters of October 2002 and September 2016.

pada kondisi cuaca yang sama, perbedaaan kondisi oseanografi pasang surut ternyata memberikan pengaruh yang signifikan terhadap perbedaan konsentrasi TSM di estuari Perancak.

\section{Informasi Perubahan Luas Mangrove di Estuari Perancak}

Luas tutupan hutan mangrove tahun 2005 di Estuari Perancak adalah sekitar 62 ha (Gambar 12a), pada 2015 luasan hutan mangrove mengalami peningkatan menjadi sekitar 101 ha (Gambar 12b). Secara umum, dalam kurun waktu 10 tahun, ekosistem mangrove di wilayah estuari Perancak mengalami penambahan luas sebesar sekitar 39 ha $(62,90 \%)$. Jika dilihat secara lebih detail dengan menggunakan analisis tumpang susun, maka akan terlihat bahwa penambahan luas total sebesar 39 ha tersebut terdiri dari 2 komponen, yaitu pada periode tahun 2005 - 2015 sebenarnya terjadi penambahan luasan hutan mangrove sebesar 51 ha (Gambar 12d) dan pada saat yang bersamaan di periode tersebut terjadi juga pengurangan luasan hutan mangrove seluas 12 ha (Gambar 12c) di beberapa lokasi (Hastuti et al., 2018). Uji akurasi dengan menggunakan Accuracy Assessment Using Random Points and the Semi-Automatic Classification Plugin for QGIS menunjukkan nilai akurasi sebesar $84,98 \%$ Perubahan luas hutan mangrove di estuari Perancak terjadi karena adanya proses alami dan proses penanaman kembali di lahan-lahan bekas tambak yang telah ditinggalkan. Rahmania et al. (2015) mengklasifikasikan hutan mangrove di estuari Perancak menjadi 3 kategori, yaitu : 1) mangrove alami; 2). mangrove alami yang tumbuh pada bekas lahan tambak; 3). mangrove hasil penanaman kembali. 


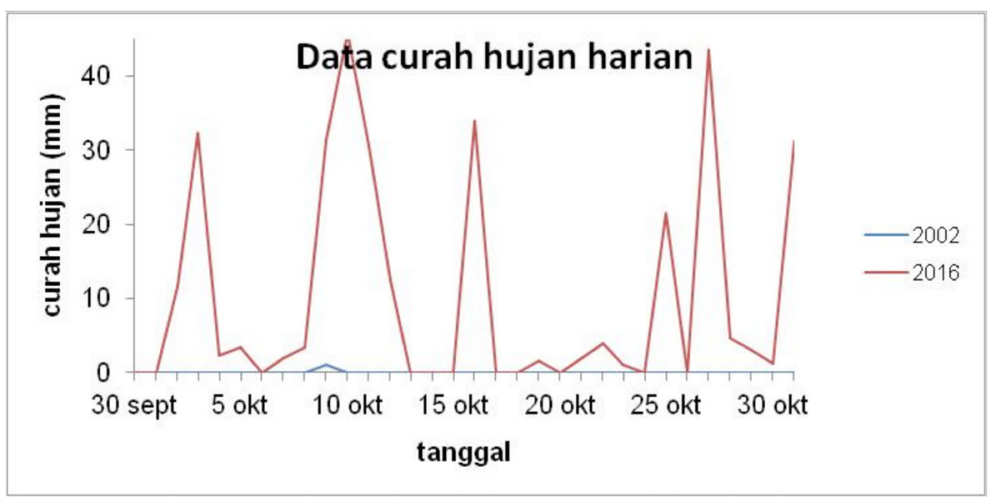

Gambar 11. Data curah hujan harian Bulan Mei tahun 2002 dan 2016.

Figure 11. Daily rainfall data for May 2002 and 2016.

Proisy et al. (2017) menyatakan bahwa berdasarkan hasil pengamatan lapangan di muara Perancak, spesies yang dominan pada kategori mangrove yang tumbuh secara alami adalah jenis Avicennia alba, Sonneratia alba, Avicennia officinalis dan Avicennia marina, sedangkan jenis spesies yang dominan pada kategori mangrove hasil penanaman adalah jenis Rhizophora mucronata, Rhizophora apiculata, Rhizophora stylosa serta sebagian kecil Avicennia alba, Avicennia marina dan Bruguiera gymnorrhiza. Penambahan luas hutan mangrove dalam kurun waktu 14 tahun terlihat sangat signifikan, berdasarkan hasil analisis Proisy et al. (2017) dengan menggunakan data penginderaan jauh resolusi tinggi, luasan hutan mangrove di estuari Perancak pada 2001 adalah sekitar 60 ha dan bertambah menjadi 125 ha pada tahun 2015 atau mengalami penambahan luas sebesar $108.33 \%$. Perbedaan hasil perhitungan luasan mangrove antara citra Landsat dengan citra resolusi tinggi diduga terjadi karena 2 hal, yaitu pantulan sinar matahari dan kondisi saat air pasang. Pantulan sinar matahari pada permukaan air akan menyebabkan kecerahan yang sangat tinggi sehingga dapat menghilangkan nilai pantulan yang berasal dari tanaman bakau, sedangkan kondisi pasang akan menyebabkan pohon bakau yang baru ditanam tidak akan terlihat. Posisi matahari terdiri dari 2 variabel, yaitu azimuth dan elevasi. Azimuth menandakan sudut terhadap utara (azimuth $0^{\circ}$ sama dengan arah utara, azimuth $90^{\circ}$ berarti kita berputar searah jarum jam sebesar $90^{\circ}$, sehingga kita menghadap ke timur dan seterusnya) sedangkan elevasi sudut yang menandakan posisi matahari (pada saat matahari terbit dikatakan elevasi $0^{\circ}$ dan ketika matahari tepat diatas kita disebut elevasi $90^{\circ}$ atau dikenal juga dengan istilah zenith). Waktu akusisi data citra satelit Landsat tanggal 28 Agustus 2015 menunjukkan waktu 02.02.46 UCT atau pukul 10.29.46 WITA dengan sun azimuth $57,52034702^{\circ}$ dan sun elevasi $56,05590160^{\circ}$. Kondisi pasut pada saat itu masih pasang ( 1 jam setelah pasang tertinggi dan 5 jam sebelum surut terendah) serta posisi matahari yang cukup tinggi, yang ditunjukkan oleh sun azimuth dan elevasi menyebabkan akusisi data Landsat (sensor zenith angle $0^{\circ}$ ) cukup dipengarui oleh adanya pantulan dari sinar matahari tersebut. Hal itulah yang diduga menjadi penyebab adanya perbedaan perhitungan luasan antara citra Landsat dengan citra

\begin{tabular}{|c|c|c|c|c|c|c|}
\hline & $\begin{array}{l}>E R R \\
>R e f\end{array}$ & & & & & \\
\hline V_Classification & 1.0 & 2.0 & 3.0 & 4.0 & 10,0 & 11.0 \\
\hline 1.0 & 7605 & 0 & 0 & 0 & 0 & 0 \\
\hline 2.0 & 386 & 0 & 0 & 0 & 0 & 0 \\
\hline 3.0 & 264 & 0 & 0 & 0 & 0 & 0 \\
\hline 4.0 & 0 & 0 & 0 & 0 & 0 & 0 \\
\hline 10.0 & 0 & 0 & 0 & 136 & 0 & 0 \\
\hline 11.0 & 0 & 320 & 4 & 0 & 0 & 0 \\
\hline 12,0 & 0 & 7 & 77 & 0 & 0 & 0 \\
\hline 14.0 & 0 & 0 & 15 & 0 & 0 & 0 \\
\hline 15.0 & 0 & 0 & 109 & 0 & 0 & 0 \\
\hline 19.0 & 0 & 0 & 9 & 0 & 0 & 0 \\
\hline 21.0 & 0 & 0 & 17 & 0 & 0 & 0 \\
\hline Total & 8255 & 327 & 231 & 136 & 0 & 0 \\
\hline
\end{tabular}

Gambar 12. Perhitungan Overall Accuracy pada QGIS. Figure 12. Overall Accuracy Calculation in QGIS. 
resolusi tinggi.

Walaupun terdapat perbedaan nilai, namun hasil analisis dengan menggunakan Landsat dan data citra resolusi tinggi secara umum memberikan gambaran yang hampir sama, yaitu sama-sama memperlihatkan terjadi trend penambahan luas vegetasi mangrove di kawasan estuari Perancak. Untuk pemetaan sebaran mangrove dengan area yang luas, pemanfaatan data citra satelit Landsat masih menjadi andalan karena selain dapat diperoleh secara cuma-cuma, hasil analisisnya pun hampir sama dengan data citra resolusi tinggi. Namun untuk pemetaan mangrove dengan daerah penelitian yang lebih sempit, diperlukan data citra dengan resolusi tinggi yang lebih detail karena selain mampu memberikan informasi mengenai sebaran dan kerapatan, jenis-jenis tanaman bakaunya pun dapat diidentifikasi.

\section{Perubahan Konsentrasi TSM di Muara Perancak}

Hasil ekstraksi nilai konsentrasi TSM di muara Perancak (titik 7) pada koordinat $114,603^{\circ} \mathrm{BT}$ dan $8,402^{\circ}$ LS menunjukkan bahwa pada bulan Mei tahun 2002 dan 2016 yang diasumsikan mewakili musim kemarau dengan kondisi oseanografis dan curah hujan yang serupa, terjadi penurunan konsentrasi TSM dari 22,372 mg/l di tahun 2002 menjadi 20,349 $\mathrm{mg} / \mathrm{l}$ ditahun 2016 atau mengalami penurunan sebesar 9,94\%. Penurunan konsentrasi TSM di kawasan muara Perancak diduga erat kaitannya dengan bertambah luasnya serta bertambahnya kerapatan pohon-pohon bakau di kawasan hutan Mangrove di estuari Perancak. Sedangkan data pada 2 Oktober 2002 dan 30 September 2016 yang diasumsikan mewakili musim hujan, dengan kondisi oseanografi yang berbeda namun kondisi curah hujan yang sama, terjadi penurunan konsentrasi TSM dari 41,539 mg/l menjadi 25,128 $\mathrm{mg} / \mathrm{l}$ atau penurunan sekitar 65,31\%. Kecenderungan yang terjadi di kawasan estuari Perancak menunjukkan bahwa meningkatnya luasan hutan mangrove akan diikuti oleh penurunan konsentrasi TSM yang ada di muara Perancak (Gambar 13). Furukawa et al. (1997) menyatakan bahwa TSM sangat berhubungan erat dengan kondisi pasang surut perairan. Pada saat pasang, konsentrasi TSM bahkan dapat mencapai tiga kali lipat jika dibandingkan dengan pada saat surut. Perbedaan konsentrasi TSM antara kondisi pasang dan surut tersebut mengindikasikan bahwa terjadi proses pengendapan sedimen di kawasan hutan mangrove karena saat pasang terdapat lebih banyak TSM yang masuk kedalam kawasan mangrove, dibandingkan dengan TSM yang keluar pada saat surut. Roza (2016) menyatakan bahwa kerapatan mangrove terutama jenis Rhizophora, karena struktur akar tunjangnya mampu berperan sebagai perangkap sedimen. Hal ini berlaku juga di kawasan estuari Perancak yang terdiri dari jenis mangrove Rhizophora, Avicennia, Sonneratia dan Bruguiera. Sidik (2014) menyatakan bahwa kenaikan permukaan tanah di kawasan estuari Perancak adalah sebesar $0,9 \mathrm{~cm} /$ tahun pada daerah penanaman kembali serta $1,1 \mathrm{~cm} /$ tahun pada daerah mangrove alami. Nilai ini relatif tinggi jika dibandingkan dengan hasil

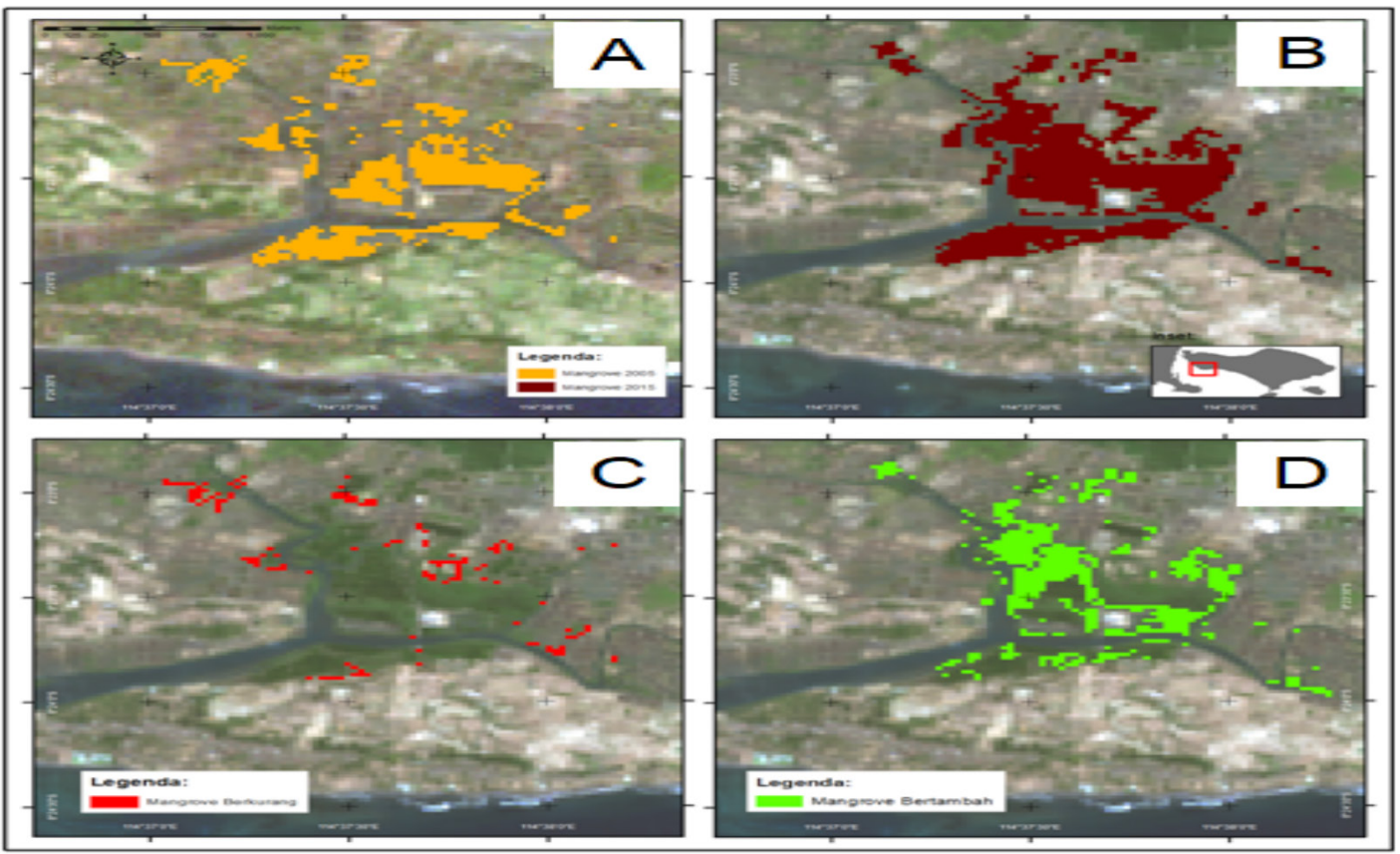

Gambar 13. Perubahan luas mangrove di Estuari Perancak pada 2005 dan 2015. Figure 13. Change in mangrove area in Perancak Estuary in 2005 and 2015.

Pengaruh Perubahan Luas Hutan Mangrove Terhadap Konsentrasi Total Suspended Matter (TSM) di Muara Perancak, Jembrana - Bali - Komang Iwan Suniada \& Liuta Yamano Aden 


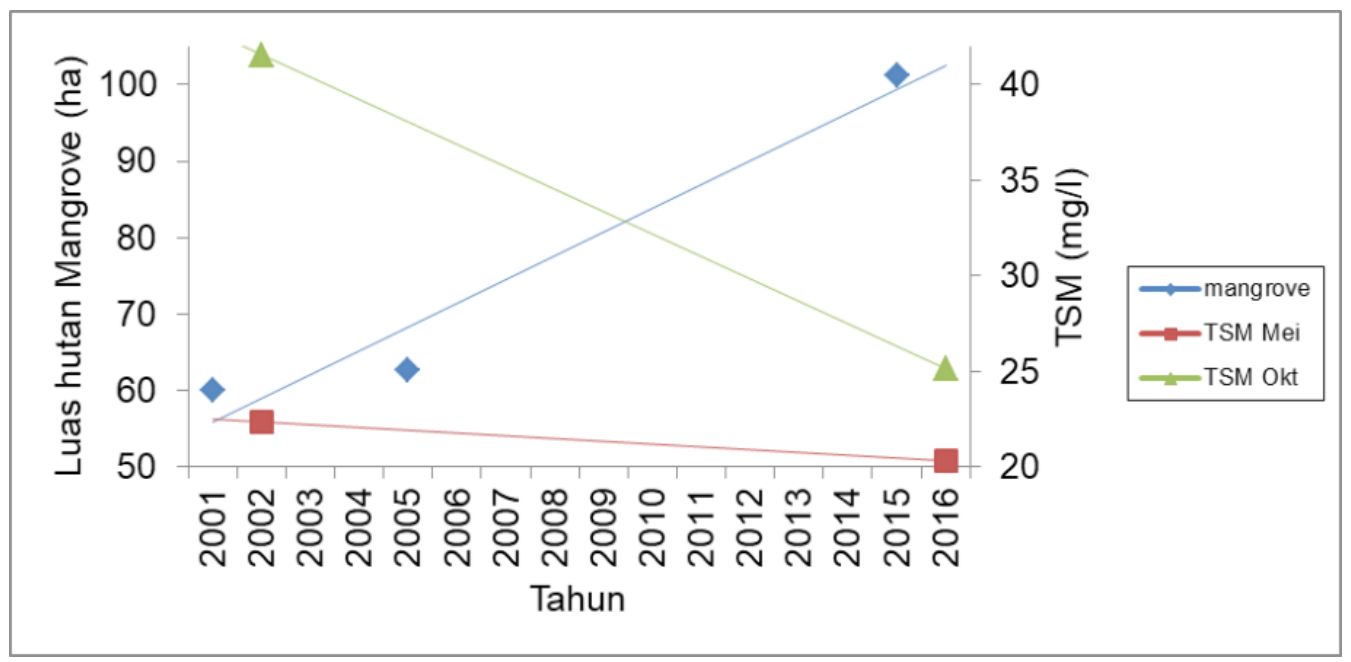

Gambar 14. Trend luas hutan mangrove versus TSM.

Figure 14. Total of mangrove area versus TSM.

penelitian Cahoon \& Lynch (1997) yang menyatakan bahwa perubahan ketinggian permukaan tanah di hutan mangrove barat daya Florida sekitar 0,06 - 0,37 cm/ tahun; serta hasil penelitian Lovelock et al. (2011) yang menyatakan bahwa perubahan ketinggian permukaan tanah di Moreton Bay, Australia adalah sebesar 0,14 dan $0,59 \mathrm{~cm} /$ tahun. Penambahan luas hutan mangrove di kawasan estuari Perancak melalui proses penanaman kembali serta pertumbuhan mangrove dari tahun ke tahun akan menyebabkan meningkatnya kerapatan antar tanaman. Semakin tingginya kerapatan tanaman mangrove akan menyebabkan semakin banyak sedimen yang terperangkap dan mengendap di kawasan estuari sehingga berdampak pada kenaikan permukaan tanah di kawasan mangrove serta berkurangnya aliran sedimen ke arah laut.

\section{KESIMPULAN DAN SARAN}

Pemanfaatan data Landsat yang merupakan data satelit penginderaan jauh resolusi menengah, dapat digunakan untuk pengamatan parameter TSM dan pengamatan perubahan luasan hutan mangrove (akurasi 84,98\%) di kawasan Estuari Perancak secara berkala. Dengan menggunakan data Landsat dapat diketahui bahwa dalam kurun waktu 10 tahun (20052015) telah terjadi penambahan luas hutan mangrove di kawasan estuari sebesar sekitar 39 ha $(62,90 \%)$. Penambahan luas tersebut memberikan pengaruh terhadap berkurangnya konsentrasi TSM yang terjadi di sekitar muara Perancak, dengan penurunan yang terjadi sebesar 8,86\% dalam kurun waktu Mei 2002 Mei 2016 (musim kemarau) serta penurunan sebesar $65,31 \%$ pada waktu musim hujan. Selain penambahan luas mangrove, faktor oseanografi pasang surut sangat berperan dalam pergerakan massa air dan fluktuasi konsentrasi TSM yang terjadi di sekitar kawasan muara Perancak.

\section{UCAPAN TERIMA KASIH}

Kepala Balai Riset dan Observasi Laut atas dukungannya, ibu Frida Sidik atas diskusinya serta team IT dan Sarpras BROL atas perhatiannya sehingga fasilitas koneksi internet dan alat pengolah data dapat tersedia dengan baik dan memadai.

\section{DAFTAR PUSTAKA}

Alimundi, S., Susilo, S.B., \& Panjaitan, J.P. (2017). Deteksi Perubahan Luasan Mangrove menggunakan Citra Landsat berdasarkan Metode Obia di Teluk Valentine Pulau Buano Seram Bagian Barat, Jurnal Teknologi Perikanan dan Kelautan, (8)1, 139-146.

Budhiman, S. (2004). Mapping TSM Concentrations from Mu/tisensor Satellite Images in Turbid Tropical Coastal Waters of Mahakam Delta-Indonesia. Master thesis. Netherland.

Budhiman, S. (2005). Pemetaan Sebaran Total Suspended Matter (TSM) menggunakan Data Aster dengan Pendekatan Bio-Optocal Model. Prosiding Pertemuan Ilmiah Tahunan MAPIN XIV, 1-6.

Cahoon, D. R. \& Lynch, J. C. (1997). Vertical accretion and shallow subsidence in a mangrove forest of southwestern Florida, USA, Mangroves and Salt Marshes, (1)3, 173-186.

Donato, D. C., Kauffman, J. B., Murdiyarso, D., Kurnianto, S., Stidham, M., \& Kannine, M. (2011). Mangroves Among The Most Carbon-Rich Forests in The Tropics, Nature Geoscience, 4, 293-297. DOI:10.1038/ NGEO1123

Furukawa, K., Wolanski, E., \& Mueller, H. (1997). Current 
and Sediment Transport in Mangrove Forests, Estuarine, Coastal and Shelf Science, 44(3), 301-310.

Haryani, N. S. (2013). Analisis Perubahan hutan mangrove menggunakan citra Landsat, Jurnal Ilmiah Widya, (1) $1,72-77$

Hastuti, A. W., Suniada, K. I. \& Islamy, F. (2017). Carbon Stock Estimation of Mangrove Vegetation using Remote Sensing in Perancak Estuary, Jembrana District, Bali, International Journal of Remote Sensing and Earth Science, (14)2, 137-150.

Hastuti, A.W., Suniada, K. I., \& Aden, L.Y. (2018). Pemetaan dan Deteksi Perubahan Mangrove menggunakan Citra Landsat Multi-Temporal di Pulau Bali, Indonesia. Prosiding Seminar Nasional Penginderaan Jauh ke-5. 309-316.

Jhonnerie, R., Siregar, V. P., Nababan, B., Prasetyo, L. B., \& Wouthuyzen, S. (2014). Deteksi Perubahan Mangrove Menggunakan Citra Landsat Berdasarkan Klasifikasi Hibrida di Sungai Kembung, Pulau Bengkalis, Provinsi Riau, Jurnal Ilmu dan Teknologi Kelautan Tropis, (6)2, 491-506.

Komiyama, A., Ong, J. E., \& Poungparn, S. (2008). Allometry, Biomass and Productivity of Mangrove Forest: A review, Aquatic Botany (89)2, 128-137.

Lovelock C. E., Bennion V., Grinham, A., \& Cahoon, D. R. (2011). The Role of Surface and Subsurface Processes in Keeping Pace With Sea Level Rise in Intertidal Wetlands of Moreton Bay, Queensland, Australia. Ecosystems, (14)5, 745-757.

Marini, Y., Emiyati., Hawariyah, S., \& Hartuti, M. (2014). Perbandingan Metode Klasifikasi Supervised Maximum Likelihood dengan Klasifikasi Berbasis Objek untuk Inventarisasi Lahan Tambak di Kabupaten Maros. Prosiding Seminar Nasional Penginderaan Jauh LAPAN. Hal 505-516.

Misra, A., Murali, R. M., Sukumaran, S., \& Vethamony, P. (2014). Seasonal Variations of Total Suspended Matter (TSM) in the Gulf of Khambhat, West Coast of India. Indian Journals of Geo-Marine Sciences, 43(7), 1202-1209.

Petra, J. L., Sastrawibawa, S., \& Riyantini, I. (2012). Pengaruh Kerapatan Mangrove Terhadap Laju Sedimen Transpor di Pantai Karangsong Kabupaten Indramayu. Jurnal Perikanan dan Kelautan, (3)3, 329-337.

Proisy, C., Viennois, G., Sidik, F., Andayani, A., Enright, J. A., Guitet, S., Gusmawati, N., Lemonnier, H., Muthusankar, G., Olagoke, A., Prosperi, J., Rahmania, R., Ricout, A., Soulard, B., \& Suhardjono. (2017). Monitoring mangrove forests after aquaculture abandonment using time series of very high spatial resolution satellite image : A case study from Perancak estuary, Bali, Indonesia. Marine Pollution Bulletin, 131(Part B), 61-71. https://doi.org/10.1016/j. marpolbul.2017.05.056.

Purwanto, A. D., Asriningrum, W., Winarso, G., \& Parwati. E. (2014). Analisis Sebaran dan Kerapatan Mangrove menggunakan Citra Landsat 8 di Segara Anakan,
Cilacap. Prosiding Seminar Nasional Penginderaan Jauh LAPAN. 232-241.

Rahmania, R., Proisy, C., Viennois, G., Andayani, A., Baudel, S., Farhan, R., Subki, B., Lemonnier, H., Gusmawati, N.F., Gaspar, P., Germain, O., Prosperi, J., Widagti, N., Sidik, F., \& Suhardjono. (2015). 13 Years of Changes in The Extent and Physiognomy of Mangroves After Shrimp Farming Abandonment, Bali. 8th International Workshop on the Analysis Multitemporal Remote Sensing Images (MultiTemporal). IEEE Explore. doi: 10.1109/MultiTemp.2015.7245801.

Roza, S. Y. (2016). Kontribusi Mangrove dalam Memerangkap Sedimen di Wilayah Pesisir Kota Dumai Provinsi Riau. Master Thesis. Institut Pertanian Bogor.

Satriadi, A., \& Widada, S. (2004). Distribusi Muatan Padatan Tersuspensi di Muara Sungai Bodri, Kabupaten Kendal. Jurnal Ilmu Kelautan, 9(2), 101-107.

Schmitt, K., \& Duke, N. C. (2015). Mangrove management, Assesment and Monitoring. Tropical Forestry Handbook, Springer-Verlag, 1-29. DOI 10.1007/9783-642-41554-8_126-1

Sidik, F. (2014). Chapter 4 : Surface Elevation Change in Restored and Natural Mangrove Forests in the Perancak Estuary, Bali. Doctor of Philosophy Thesis. The University of Queensland.

Spalding, M., Mclvor, A., Tonneijck, F. H., Tol, S., \& Van Eijk, P. (2014). Mangroves for coastal defence : Guidelines for coastal managers and policy makers. Wetlands International and The Nature Conservancy. $42 \mathrm{p}$.

Sulong, I., Lokman, H. M., Tarmizi, K. M., \& Ismail, A. (2002). Mangrove mapping using Landsat imagery and aerial photographs : Kemaman District, Trengganu, Malaysia. Environment, Development and Sustainability, (4)2, 135-152.

Wibowo, Y. S. A., Hariadi., \& Marwoto, J. (2016). Pengaruh Arus Laut dan Pasang Surut terhadap Distribusi Sedimen Tersuspensi di Perairan Muara Sungai Sembilangan Kaliprau Pemalang. Jurnal Oseanografi (5)4, 490-497. 
